\title{
Quran and Metonymy: \\ Literal, Semantic and Metonymic Translation (Analysis of English Translation of a Quranic Verse)
}

\author{
Dr. Shiar Ali Khan ${ }^{1}$ \\ Dr. Abdul Mujeeb Bassam ${ }^{2}$ \\ Dr. Zainab Amin ${ }^{3}$
}

ISSN (P) 2664-0031 (E) 2664-0023

Received: January 17,2021

DOI: https://doi.org/10.37605/fahmiislam.v4i1.132

\begin{abstract}
Metonymy is a rhetorical device widely used in the literary works of all the times. At the time when Quran was revealed the Arab were on the top of such idiomatic and rhetorical style of speech. Metonymy is the way to a hidden meaning or a far meaning from the apparent one. Translating metonymy creates problems while finding out the intended, desired and hidden meaning. These problems turn critical during translating the 'Word of Heaven'. I have selected two consecutive metonymic phrases of Verse No. 43 of Chapter: The Women which is as under:

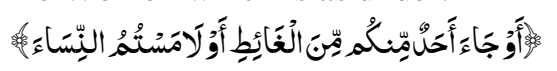

A total number of 32 Quran translators are randomly selected to find out the literal, semantic and metonymic translations of these two metonymic phrases. We can easily observe the various kinds of translation, sentence style, and shifts that create complexity for those readers who depend on translation. The paper quoted the stances of the Exegetes of Quran regarding these two adjacent metonymic sentences, determining the meaning mentioned by the majority of Exegetes and analyzde the English words used for rendering their meanings to find out which translation can be suggested for the source language general public to gain the real intended meaning as elaborated by the majority of Quran Exegetes.
\end{abstract}

Keywords: Metonymy; Literal Translation; Semantic Translation; Metonymic Translation

1 Assistant Professor, Department of Translation \& Interpretation, Faculty of Arabic, International Islamic University Islamabad Pakistan. Email: shair.ali@iiu.edu.pk

2 Assistant Professor, Department of Literature, Faculty of Arabic International Islamic University Islamabad

3 Assistant Professor, Women University Peshawar 


\section{Introduction}

Metonymy is considered a 'figure of speech' in the words of Jeannette Littlemore, calling it as a key component of our daily life thinking process. (Metonymy 2015: 191). World history proves that Arab possess instinct linguistic minds, with unrivaled memorizing ability and a terrifying fluency of speech and oratory due to which they considered themselves the most powerful speech clans at the time. The Arabic language has the capacity of absorbing a vast variety of linguistic and rhetorical devices, tools, in a variety of vocabulary. After the revelation of Quran, a terminological, linguistic and especially literary explosion took place in the history of world religion and linguistics. This feature made the translation of Quran a complex challenging activity. That is why we see a linguistic variation in the translations of Quran and even in a single Quranic term, phrase, proverb and cultural meaning career. Metonymy has been used in Quran for a variety of purposes sometimes to convey a cultural habit or sometimes to take care of religious boundaries. The article in hand discusses two consecutive parts of a metonymic verse which contains both cultural and religious characteristics. But, some translations convey the literal meaning, some of them convey the semantic meaning and some contain metonymic meaning.

\section{Methodology}

The study is descriptive and comparative in nature. I have a verse in which adjacently two metonymic devices are used both relate to the cultural tradition of Arab, both have been secret actions of their life. Quran, the book of guidance mentioned both traditions.

\section{Theoretical Framework}

For, this research Peter Newmark theoretical framework has been applied. The definitions of literal, semantic and idiomatic or in other words (metonymical) translation are as under:

Literal Translation: Newmark defined literal translation as "the source language grammatical constructions are converted to their nearest TL equivalents but the lexical word is again translated singly, out of context." (Newmark 1988: 46)

Semantic Translation: Newmark defined it as "it differs from faithful translation as it must take more account of the aesthetic value (that is, the beautiful and natural sounds of the SL text,) compromising on 'meaning', where appropriate so that no assonance, word-play or repetition jars in the finish version. It may translate less important cultural words by culturally 
neutral third or functional terms but not by cultural equivalent..... It is more flexible in view of faithful translation and admits the creative exception to $100 \%$ fidelity and allows for the translator's intuitive empathy with the original." (Newark1988:46)

Idiomatic Translation: "It produces the 'message' of the original but tends to distort nuances of meaning by preferring colloquialism and idioms where these do not exist in the original...". (Newmark 1988: 47)

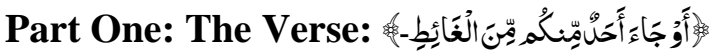

\section{Meaning of (الغائط):}

The word in the verse contains various meanings as Hans Wehr (1976: 688) mentioned two meanings:

- Human excrement

- Feces

It is derived from the verb (غاط غوطا) that means according to Hans Wehr:

- To deepen, make deeper (a well)

- Verb form number V, means: to evacuate the bowels, relieve nature,

And the meaning of (غوط) as a noun is: cavity, hollow, depression.

The Arab lexicographer Ibni Manzoor (7:364-365) narrated the meaning of this word in his dictionary 'Lisanaul Arab': The word (الغوط) means

1. 'depth of the earth and remoteness',

2. the part of land where one feel satisfaction,

We can extract from Ibni Manzoor three main points:

- deep hiding place;

- far away from the residential area;

- Secure land where one feels satisfaction of security.

Therefore, according to Ibni Manzoor the word (غائط) has been used for a 'far away land with hiding places where one hides himself and gets relieved with the sense of satisfaction that no one can see him here'. It shows the Arab cultural habit of going far away from home to relieve in a satisfied place.

- Abu Hanifa's views are 'the deep part of the germinated earth'.

- It means every dipped part of the earth, metonymically used for relieving, it includes all impurities.

- It means the safe part of the earth. (Al-Razi: V. 43), then the same word was used for 'relieving'. 
- الغائط (التغويط) is metonymy for excrement whereas, the word is the name of stool, feces because it was thrown in the deep part of the earth. (Ibni Katheer)

- It should be probably away 4 Kilometers.

Qurtabi mentioned the meaning of (الغائط) ' the valley'. ' Tabrasi mentioned that it means 'relieving oneself, defecating'. ${ }^{2}$ Ibni Kathir said that it means ' protected part of land' metonymically used for 'defecating'. ${ }^{3}$ Al-Shokani and Ibni Kathir said that it is 'steep land'.

\section{Various Translations}

The translators translated the metonymic sentence in varied structures and styles. The details of various translations are mentioned as under:

1- privy

\begin{tabular}{|c|c|c|c|}
\hline S.\# & $\begin{array}{l}\text { Translator's } \\
\text { Name }\end{array}$ & Translation & Variation \\
\hline 1 & Shakir & $\begin{array}{l}\text { or one of you come from the } \\
\text { privy }\end{array}$ & Come - privy \\
\hline 2 & $\begin{array}{l}\text { Dr. Laleh } \\
\text { Bakhtiar }\end{array}$ & $\begin{array}{l}\text { one of you drew near from the } \\
\text { privy }\end{array}$ & $\begin{array}{l}\text { drew near - } \\
\text { privy }\end{array}$ \\
\hline 3 & $\begin{array}{l}\text { Abdul Majid } \\
\text { Daryabadi }\end{array}$ & $\begin{array}{l}\text { or one of you cometh from the } \\
\text { privy }\end{array}$ & $\begin{array}{l}\text { Cometh from- } \\
\text { privy }\end{array}$ \\
\hline 4 & $\begin{array}{l}\text { Muhammad } \\
\text { Mahmoud Ghali }\end{array}$ & $\begin{array}{l}\text { or (in case) any of you comes } \\
\text { from the privy }\end{array}$ & $\begin{array}{l}\text { comes from the } \\
\text { privy }\end{array}$ \\
\hline 5 & Shabbir Ahmed & or coming from the privy, & privy \\
\hline 6 & $\begin{array}{l}\text { Arthur John } \\
\text { Arberry }\end{array}$ & $\begin{array}{l}\text { or if any of you comes from } \\
\text { the privy, }\end{array}$ & privy \\
\hline 7 & $\begin{array}{l}\text { Edward Henry } \\
\text { Palmer }\end{array}$ & $\begin{array}{l}\text { or one of you come from the } \\
\text { privy, }\end{array}$ & privy \\
\hline 8 & $\begin{array}{l}\text { Sayyed Abbas } \\
\text { Sadr-Ameli }\end{array}$ & or one of you come from privy & privy \\
\hline
\end{tabular}

Meaning of Privy: The word "privy" is attested from Old French 'prive' in the meaning of 'private place' in early 13 oo century. ${ }^{4}$ It means 'a toilet in a small shed outside a house or other building'. ${ }^{5}$ or 'a toilet' ${ }^{\text {' }}$

Analysis: The word used in the Quran denotes the cultural tradition of Arabs in terms of relieving. The translation contains semantic ingredients of the Arabic word except the metonymic meaning. This is a semantic translation the verse. 
2- Closet

\begin{tabular}{|l|l|l|l|}
\hline S. \# & Translator's Name & Translation & Variation \\
\hline 1 & M. M. Pickthall & $\begin{array}{l}\text { or one of you cometh } \\
\text { from the closet, }\end{array}$ & $\begin{array}{l}\text { cometh from the } \\
\text { closet, }\end{array}$ \\
\hline
\end{tabular}

Meaning of Closet: As a noun it means in English 'secret, private room for study or prayer', as an adjective it means 'secret and unknown' ${ }^{7}$ It means as well 'a toilet'.

Analysis: This translation contains the sense of secrecy of Arab cultural mentality as they use secret places for cleanliness. It lacks the metonymic sense of the verse. Therefore, it is a semantic translation of the verse.

3- Relieved

\begin{tabular}{|l|l|l|l|}
\hline S. \# & Translator's Name & Translation & Variation \\
\hline 1 & Wahiduddin Khan & have relieved yourselves & relieved yourselves \\
\hline 2 & Safi Kaskas & have relieved yourselves & relieved yourselves \\
\hline 3 & Abdel Haleem & have relieved yourselves & relieved yourselves \\
\hline 4 & Wahiduddin Khan & have relieved yourselves & relieved yourselves \\
\hline 5 & $\begin{array}{l}\text { N J Dawood } \\
\text { (draft) }\end{array}$ & $\begin{array}{l}\text { or if, when you have } \\
\text { relieved yourselves }\end{array}$ & $\begin{array}{l}\text { relieved } \\
\text { yourselves }\end{array}$ \\
\hline
\end{tabular}

Meaning of Relieve: It means 'to ease or alleviate ( pain, distress, anxiety, need) and as an idiom used ' to relieve oneself' means ' urinate or defecate' 8 ; 'to relieve the bladder or bowels of (oneself). ${ }^{9}$

Analysis: The translation lacks the meaning of cultural tradition of going far away for relieving, the semantic ingredients of the Arabic word, but it directly denotes the action of relieving which is the metonymic sense of the translation so it is a metonymic translation.

4- Lavatory:

\begin{tabular}{|l|l|l|l|}
\hline S. \# & Translator's Name & Translation & Variation \\
\hline 1 & Aisha Bewley & $\begin{array}{l}\text { or any of you have come } \\
\text { from the lavatory }\end{array}$ & $\begin{array}{l}\text { come from the } \\
\text { lavatory }\end{array}$ \\
\hline
\end{tabular}

Meaning of Lavatory: it means in $14^{\text {th }}$ century Latin "washbasin", "Place for washing", and sense of "washroom" in 1650 as euphemism for "toilet". In modern sense it means "the washroom with all facilities"10 ; according to Webster's 'a room with conveniences for washing and usually with one or more toilets'.

Analysis: The translation only shows the place of washing and cleanliness. So, it will lack the cultural, geographical and metonymic senses of the Arabic word, whereas, it provides the semantic meaning. So it is a semantic translation of the verse. 
5- Defecated:

\begin{tabular}{|l|l|l|l|}
\hline S. \# & Translator's Name & Translation & Variation \\
\hline 1 & $\begin{array}{l}\text { Muhammad } \\
\text { Sarwar }\end{array}$ & $\begin{array}{l}\text { you can find no water } \\
\text { after having defecated }\end{array}$ & defecated \\
\hline
\end{tabular}

Meaning of Defecated: Its primary meaning is "to purify", evolved to "cleanse from dregs, purify", then the sense of "excretory" first recorded in 1830. ${ }^{11}$ According to Webster's Dictionary it means 'to discharge through the anus: to discharge feces from the bowels' ${ }^{12}$

Analysis: The translation shows only the last result of all this purifying activity. So it lacks the cultural and semantic senses and denotes the metonymical sense. It is a metonymic translation of the verse.

\section{6- Call of Nature}

\begin{tabular}{|l|l|l|l|}
\hline S. \# & Translator's Name & Translation & Variation V.1 \\
\hline 1 & $\begin{array}{l}\text { Dr. Mohammad } \\
\text { Tahir-ul-Qadri }\end{array}$ & $\begin{array}{l}\text { or return from a call of } \\
\text { nature }\end{array}$ & call of nature \\
\hline 2 & $\begin{array}{l}\text { Muhsin Khan \& } \\
\text { Muhammad al-Hilali }\end{array}$ & $\begin{array}{l}\text { or one of you comes after } \\
\text { answering the call of nature }\end{array}$ & call of nature \\
\hline 3 & Ali Ünal & $\begin{array}{l}\text { or if any of you has just } \\
\text { satisfied a call of nature }\end{array}$ & $\begin{array}{l}\text { satisfied a call } \\
\text { of nature }\end{array}$ \\
\hline 4 & $\begin{array}{l}\text { Yusuf Ali (Saudi } \\
\text { Rev. 1985) }\end{array}$ & $\begin{array}{l}\text { or one of you cometh } \\
\text { from offices of nature }\end{array}$ & $\begin{array}{l}\text { cometh from } \\
\text { offices of nature }\end{array}$ \\
\hline 5 & George Sale & $\begin{array}{l}\text { or any of you come from } \\
\text { easing nature }\end{array}$ & easing nature \\
\hline
\end{tabular}

Meaning of Call of Nature: The noun phrase is originated in 1800s for the meaning of 'a need to urinate or defecate, or to use a toilet in urgent case' but now is dying out; ${ }^{13}$ 'the need to use the toilet; ${ }^{14}$ 'the need to go to the lavatory. ${ }^{15}$

Analysis: Whether the translation is with an idiomatic expression which focuses on the 'need of using toilet or lavatory', it does not clarify the real situation of the user. It lacks the cultural and religious features, but somewhat explains the metonymical nature of the verse. It can be put in the metonymic translation.

7- Place of Relieving

\begin{tabular}{|l|l|l|l|}
\hline S. \# & Translator's Name & Translation & Variation \\
\hline 1 & $\begin{array}{l}\text { Umm Muhammad } \\
\text { (Sahih International) }\end{array}$ & $\begin{array}{l}\text { or one of you comes } \\
\text { from the place of } \\
\text { relieving himself }\end{array}$ & $\begin{array}{l}\text { place of } \\
\text { relieving }\end{array}$ \\
\hline 2 & Ahmed Hulusi & $\begin{array}{l}\text { or come from the } \\
\text { place of relieving } \\
\text { yourselves (lavatory) }\end{array}$ & $\begin{array}{l}\text { place of relieving } \\
\text { yourselves } \\
\text { (lavatory) }\end{array}$ \\
\hline
\end{tabular}


Meaning of Relieve: Place of Relieving: the coined phrase denotes the semantic nature of the Arabic word.

Analysis: The translation is literal in sentence structure, but semantic in the translation of the main word "الغائط" that focuses on the place where this natural activity has been done. So it may be put in semantic translation.

\section{8-Relieving Himself:}

\begin{tabular}{|l|l|l|l|}
\hline S.\# & Translator's Name & Translation & Variation \\
\hline 1 & $\begin{array}{l}\text { Muhammad Taqi } \\
\text { Usmani }\end{array}$ & $\begin{array}{l}\text { or if one of you has come } \\
\text { after relieving himself }\end{array}$ & $\begin{array}{l}\text { comes after } \\
\text { relieving himself }\end{array}$ \\
\hline
\end{tabular}

Meaning of Relieve: Idiomatic use of the phrase 'relieve oneself' is to 'urinate or defecate' 16

Analysis: The translation serves the meaning of 'satisfaction' which one gets after urinating with a lack of cultural, religious and semantic layers. The sentence structure is literal, but the word "الغائط" has been translated with metonymic sense. It is literal in sentence structure but metonymic in meaning. So, I considered it metonymic translation.

\section{9- Toilet}

\begin{tabular}{|l|l|l|l|}
\hline S. \# & Translator's Name & Translation & Variation \\
\hline 1 & $\begin{array}{l}\text { Dr. Munir } \\
\text { Munshey }\end{array}$ & $\begin{array}{l}\text { or if any of you has been } \\
\text { to the toilet }\end{array}$ & toilet \\
\hline 2 & T.B.Irving & $\begin{array}{l}\text { or one of you has come } \\
\text { from the toilet }\end{array}$ & $\begin{array}{l}\text { come from the } \\
\text { toilet }\end{array}$ \\
\hline 3 & Farook Malik & $\begin{array}{l}\text { or one of you has used the } \\
\text { toilet }\end{array}$ & toilet \\
\hline 4 & Ali Quli Qara'i & $\begin{array}{l}\text { or any of you has come } \\
\text { from the toilet }\end{array}$ & $\begin{array}{l}\text { come from the } \\
\text { toilet }\end{array}$ \\
\hline 5 & Dr. Kamal Omar & $\begin{array}{l}\text { or one of you has come out } \\
\text { of the toilet }\end{array}$ & toilet \\
\hline 6 & Sayyid Qutb & $\begin{array}{l}\text { or if one of you has come } \\
\text { from the toilet }\end{array}$ & toilet \\
\hline 7 & Mir Aneesuddin & $\begin{array}{l}\text { or one of you comes from } \\
\text { the toilet }\end{array}$ & toilet \\
\hline
\end{tabular}

Meaning of Toilet: the use of this word as 'dressing room with an attached lavatory' was attested in 1819 , then 'lavatory or porcelain plumbing fixture' in $1895 .^{17}$

Analysis: The translation only serves the meaning of place where one urinates. The word 'toilet' contains all the modern relevant requisites of a 'toilet'. It lacks the metonymical meaning of the holy phrase. It is semantic translation. 


\section{0- Unclean Place}

\begin{tabular}{|l|l|l|l|}
\hline S. \# & Translator's Name & Translation & Variation V.1 \\
\hline 1 & $\begin{array}{l}\text { John Medows } \\
\text { Rodwell }\end{array}$ & $\begin{array}{l}\text { or have come from the } \\
\text { unclean place }\end{array}$ & unclean place \\
\hline
\end{tabular}

Meaning of Unclean Place: The word 'unclean' used in the sense of 'dirty' in mid $13^{\text {th }}$ century. The phrase 'unclean place' means the place lacks moral, spiritual, ritual or physical cleanliness. ${ }^{18}$

Analysis: Here the translation shows the physical situation of the place where one gets easy and relieved. So it as well lacks the metonymy of the holy text. Whereas, the word unclean place does not serve the exact meaning of the verse. There is an semantic ambiguity in this word. I consider it a semantic type of translation.

\section{Final Analysis of the Translations}

I have selected 32 English translators randomly. Some of these translations are literal in terms of sentence structure but the main word that contains metonymy has been translated with semantic meaning. So I recorded them under category of semantic translations.

\begin{tabular}{|c|c|c|c|c|}
\hline S. \# & $\begin{array}{c}\text { Literal } \\
\text { Translation }\end{array}$ & $\begin{array}{c}\text { Semantic } \\
\text { Translation }\end{array}$ & $\begin{array}{c}\text { Metonymical } \\
\text { Translation }\end{array}$ & $\begin{array}{c}\text { Number of } \\
\text { Translators }\end{array}$ \\
\hline 1 & & Privy & & 8 \\
\hline 2 & & Closet & & 1 \\
\hline 3 & & Relieved & 5 \\
\hline 4 & & Lavatory & & 1 \\
\hline 5 & & & Defecated & 1 \\
\hline 6 & & $\begin{array}{c}\text { Place of } \\
\text { Relieving }\end{array}$ & & 5 \\
\hline 7 & & & $\begin{array}{c}\text { Relieving } \\
\text { Himself }\end{array}$ & 1 \\
\hline 8 & & Toilet & & 7 \\
\hline 9 & & Unclean Place & & 1 \\
\hline 10 & & & & 2 \\
\hline
\end{tabular}

Six kinds of words have been used for rendering the semantic type of translation by twenty translators and four kinds of words have been used for metonymical translation by twelve translators. Whereas, I found some literal translations in terms of sentence structure that contain semantic meaning of the metonymic word. 


\section{Kinds of Translation Literal $0 \%$}

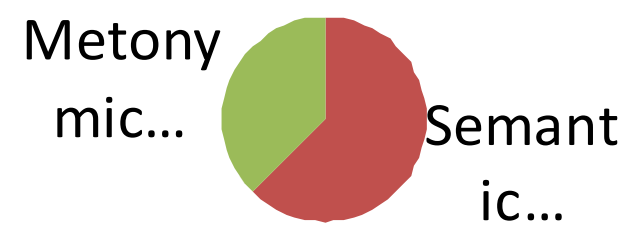

The table shows the number of semantic and metonymic translations.

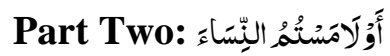

Dictionary Meaning of (لامس):

Hans Wehr (1976: 879) mentioned the following three meanings of the Arabic word (لامس):

- Touching, touch, contact;

- Feeling, fingering, palpation;

- Sexual intercourse

\section{Exegetical Meaning}

The Arab exegete Al-Tabri expounded that it means that 'having sexual intercourse with women using thier hands'. (Tabri v.43) He quoted from Saeed bin Jubair narrating from Abdullah bin Abbas about the disagreement among Freed Slaves and Arab scholars. According to the freed slaves it means 'just touching', whereas according to Arab scholars it means 'sexual intercourse'. The words 'mass, lamas, mubasharat' all contain the meanings of 'sexual intercourse, but it is the will of Lord to use the metonymical style. Another narration from Ibni Abbas is that 'mulamisa' means 'marriage; wedlock or matrimony'. ${ }^{19}$

Razi mentioned two groups of Quran scholars among them were Hamza and Kisai who read the verb "laamastum" in its trilateral form without the extra vowel "lamastum" which means just 'touching' and the other majority scholar read with extra vowel "laamastum" that means "sexual intercourse". He further mentioned two groups about its meaning:

- Ibni Abbas, al-Hasan, Mujahid, Qataada and Abu Hanifa construe it with "sexual intercouse" because according to thier view point just touching with hand does not invalidate the ablution. 
- Ibn Masood, Ibn Umer, Shaabi, Nakhii, and Imam Shafai say that “lamas' means "التقاء البشرتين meeting of two bodies either for sexual intercouse or without that". ${ }^{20}$

\section{Various Translations}

The translators adopted various tenses for this single phrase such as past indefinite, present perfect and past perfect forms. Here is the detail:

1-Literal Meaning: Touched:

\begin{tabular}{|l|l|l|l|c|}
\hline S.\# & Translator's Name & Translation & Variation & Recitation \\
\hline 1 & Aisha Bewley & or touched women, & touched & $\begin{array}{l}\text { Hamza and } \\
\text { Kisai } \\
\text { 'lamastum }\end{array}$ \\
\hline 2 & M. M. Pickthall & $\begin{array}{l}\text { or ye have touched } \\
\text { women }\end{array}$ & touched & - \\
\hline 3 & Shakir & $\begin{array}{l}\text { or you have touched } \\
\text { the women }\end{array}$ & touched & - \\
\hline 4 & $\begin{array}{l}\text { Abdul Majid } \\
\text { Daryabadi }\end{array}$ & $\begin{array}{l}\text { have touched } \\
\text { women, }\end{array}$ & touched & - \\
\hline 5 & $\begin{array}{l}\text { Ali Quli Qara'i } \\
\text { or you have touched } \\
\text { women }\end{array}$ & touched & - \\
\hline 6 & $\begin{array}{l}\text { Arthur John } \\
\text { Arberry }\end{array}$ & $\begin{array}{l}\text { or you have touched } \\
\text { women }\end{array}$ & touched & - \\
\hline 7 & $\begin{array}{l}\text { Edward Henry } \\
\text { Palmer }\end{array}$ & $\begin{array}{l}\text { or if ye have touched } \\
\text { a woman }\end{array}$ & touched & - \\
\hline 8 & $\begin{array}{l}\text { George Sale } \\
\text { or have touched } \\
\text { women }\end{array}$ & touched & - \\
\hline 9 & $\begin{array}{l}\text { John Medows } \\
\text { Rodwell }\end{array}$ & $\begin{array}{l}\text { or have touched a } \\
\text { woman }\end{array}$ & touched & - \\
\hline 10 & $\begin{array}{l}\text { Mir Aneesuddin } \\
\text { or you have touched } \\
\text { women }\end{array}$ & touched & - \\
\hline 11 & $\begin{array}{l}\text { Sayyed Abbas } \\
\text { Sadr-Ameli }\end{array}$ & $\begin{array}{l}\text { or you have touched } \\
\text { the women }\end{array}$ & touched & - \\
\hline
\end{tabular}

Meaning of "Touch": Its origin is from Middle English whereas, the Webster's New Collegiate Dictionary mentioned its meaning as 'to bring a bodily part into contact with to perceive through the tactile sense: handle or feel gently usually with the intent to understand. (Webster's 1977: 1234).

Analysis: the translation is according to the first group who read the verb in trilateral form without 'lamastum' that means 'touching'. The translation is literal in nature. 


\section{Contact:}

\begin{tabular}{|c|c|c|c|}
\hline S.\# & Translator & Translations & Variation \\
\hline 1 & $\begin{array}{l}\text { Yusuf Ali (Saudi } \\
\text { Rev. 1985) }\end{array}$ & $\begin{array}{l}\text { or ye have been in contact } \\
\text { with women }\end{array}$ & contact \\
\hline 2 & T.B.Irving & $\begin{array}{l}\text { or has had contact with any } \\
\text { women }\end{array}$ & contact \\
\hline 3 & Ali Ünal & $\begin{array}{l}\text { or you have had contact with } \\
\text { women }\end{array}$ & contact \\
\hline 4 & $\begin{array}{l}\text { Muhammad } \\
\text { Mahmoud Ghali }\end{array}$ & $\begin{array}{l}\text { or you have had contact with } \\
\text { women }\end{array}$ & contact \\
\hline 5 & $\begin{array}{l}\text { Muhammad Taqi } \\
\text { Usmani }\end{array}$ & $\begin{array}{l}\text { or you have had contact with } \\
\text { women }\end{array}$ & contact \\
\hline 6 & $\begin{array}{l}\text { Umm Muhammad } \\
\text { (Sahih International) }\end{array}$ & $\begin{array}{l}\text { or you have contacted } \\
\text { women }\end{array}$ & contactec \\
\hline
\end{tabular}

Meaning of Contact: The word's origin is from Latin 1620. It means as Webster's mentioned as verb: to bring into contact; to enter or be in contact with: join; to get in communication with; to make contact; and as noun it means 'association, relationship; connection, communication. (Webster's: 1977:244)

Analysis: The translation does not show the intended metonymical meaning of "sexual intercourse". It shows just meeting, or contacting with women. The translation is neither literal nor metonymic, but we can categorize them in semantic translation.

\section{Contact (with sexual relation):}

\begin{tabular}{|c|c|c|c|}
\hline S.\# & Translator's Name & Translation & Variation \\
\hline 1 & Farook Malik & $\begin{array}{l}\text { or has had contact with } \\
\text { women (sexual relation } \\
\text { with wives) }\end{array}$ & $\begin{array}{l}\text { contact with } \\
\text { women (sexual } \\
\text { relation with wives) }\end{array}$ \\
\hline 2 & $\begin{array}{l}\text { Muhsin Khan \& } \\
\text { Muhammad al- } \\
\text { Hilali }\end{array}$ & $\begin{array}{l}\text { or you have been in } \\
\text { contact with women } \\
\text { (by sexual relations) }\end{array}$ & $\begin{array}{l}\text { contact with } \\
\text { women (by sexual } \\
\text { relations) }\end{array}$ \\
\hline 3 & $\begin{array}{l}\text { Dr. Munir } \\
\text { Munshey }\end{array}$ & $\begin{array}{l}\text { or if you have come in } \\
\text { (sexual) contact with } \\
\text { (your) women }\end{array}$ & (sexual) contact \\
\hline 4 & Dr. Laleh Bakhtiar & $\begin{array}{l}\text { or you came into sexual } \\
\text { contact with your wives }\end{array}$ & sexual contact \\
\hline 5 & $\begin{array}{l}\text { Dr. Mohammad } \\
\text { Tahir-ul-Qadri }\end{array}$ & $\begin{array}{l}\text { or make sexual contact } \\
\text { with (your) women }\end{array}$ & sexual contact \\
\hline 6 & Dr. Kamal Omar & $\begin{array}{l}\text { or you have made } \\
\text { sexual contact with } \\
\text { women }\end{array}$ & sexual contact \\
\hline
\end{tabular}


Analysis: The translation shows the contact or meeting for sexual purpose but it does not show the intended meaning of sexual act but due to its structure we can put it under metonymic translation.

\section{Intercourse:}

\begin{tabular}{|l|l|l|l|}
\hline S. \# & Translator's Name & Translation & Variation \\
\hline 1 & Safi Kaskas & or had intercourse & intercourse \\
\hline 2 & Abdel Haleem & or had intercourse & intercourse \\
\hline 3 & $\begin{array}{l}\text { N. J. Dawood } \\
\text { (draft) }\end{array}$ & $\begin{array}{l}\text { or had intercourse with } \\
\text { women }\end{array}$ & intercourse \\
\hline 4 & Ahmed Hulusi & $\begin{array}{l}\text { or you have had sexual } \\
\text { intercourse }\end{array}$ & $\begin{array}{l}\text { sexual } \\
\text { intercourse }\end{array}$ \\
\hline
\end{tabular}

Meaning of Intercourse: The origin of the word goes to mid $15^{\text {th }}$ century in the meaning of 'communication to and from' sexual relation first recorded in $1798 .{ }^{21}$ Webster's defined the word as "physical sexual contact between individuals that involves the genitalia of at least one person (heterosexual) (Webster's 1977:602).

Analysis: The translation is metonymic as it exactly describes the sexual action which majority of the Quranic exegetes expressed in their commentaries.

\section{Cohabited:}

\begin{tabular}{|l|l|l|l|}
\hline S.\# & Translator's Name & Translation & Variation \\
\hline 1 & Mohammad Asad & $\begin{array}{l}\text { or have cohabited with a } \\
\text { woman }\end{array}$ & cohabited \\
\hline 2 & Sayyid Qutb & $\begin{array}{l}\text { or if you have cohabited } \\
\text { with a woman }\end{array}$ & cohabited \\
\hline
\end{tabular}

Meaning of Cohabit: The origin goes to 1520 in the meaning of 'to have possession; abide' and in 1530 attested the meaning of 'couple living together without marriage'22 whereas Webster's attested the meaning of 'to live together as husband and wife' ( Webster's 1977: 218)

Analysis: The translation shows the relation as wife and husband but does not show the metonymical meaning that invalidates the ablution. Whether this relation is the legal justification of having sexual intercourse with each other. So it is semantic translation.

\section{Consorted:}

\begin{tabular}{|l|l|l|l|}
\hline S. \# & Translator's Name & Translation & Variation \\
\hline 1 & Wahiduddin Khan & $\begin{array}{l}\text { or when you have consorted } \\
\text { with women }\end{array}$ & consorted \\
\hline
\end{tabular}

Meaning of Consorted: In early $15^{\text {th }}$ century, it has the meaning of a 'partner' and from Middle French it has got the meaning of 'colleague, 
partner and wife', then in 1630, the sense of 'husband or wife (partner in marriage) was attested, and as transitive verb in the meaning of 'to combine or unite or espouse'. ${ }^{23}$ Webster's mentioned the meanings of 'spouse', 'conjunction, association'. (Webster's 1977:242)

Analysis: the translation does not show the metonymical meaning, but it shows the legal marital link of the wife and husband. It will fall under semantic translation.

\section{Carnal Relations:}

\begin{tabular}{|l|l|l|l|}
\hline S. \# & Translator's Name & Translation & Variation \\
\hline 1 & $\begin{array}{l}\text { Muhammad } \\
\text { Sarwar }\end{array}$ & $\begin{array}{l}\text { or after having had carnal } \\
\text { relations, }\end{array}$ & $\begin{array}{l}\text { carnal } \\
\text { relations }\end{array}$ \\
\hline
\end{tabular}

Meaning of Carnal Relation: The origin of carnal goes back to 1400 AD Old French in the meaning of 'physical, human, mortal', and to Medieval Latin in the meaning of 'natural, of the same blood', and from Latin 'the flesh' and the meaning of 'sensual' was attested in $15^{\text {th }}$ century. The adverb "carnally" was used in the meaning of "sexually" in $1530 \mathrm{~s}^{24}$

Analysis: The translation shows the metonymic meaning of the verse.

Final Analysis of the Translations

Three kinds of translations have been found in the above verses. The table shows the detail:

\begin{tabular}{|c|c|c|c|c|}
\hline S. \# & $\begin{array}{c}\text { Literal } \\
\text { Translation }\end{array}$ & $\begin{array}{c}\text { Semantic } \\
\text { Translation }\end{array}$ & $\begin{array}{c}\text { Metonymical } \\
\text { Translation }\end{array}$ & $\begin{array}{c}\text { Number of } \\
\text { Translators }\end{array}$ \\
\hline 1 & Touched & Contact & & 11 \\
\hline 2 & & & $\begin{array}{c}\text { Contact (with } \\
\text { sexual relation) }\end{array}$ & 6 \\
\hline 3 & & & Intercourse & 4 \\
\hline 4 & & & & 2 \\
\hline 5 & & Cohabited & & 1 \\
\hline 6 & & Consorted & Carnal Relations & 1 \\
\hline 7 & & & 11 & \\
\hline & 11 & 9 & \\
\hline
\end{tabular}

The table shows that eleven translators have presented literal translations, whereas, nine translations have been rendered as semantic translation, and eleven are metonymic translations. 


\section{Kinds of Translation}

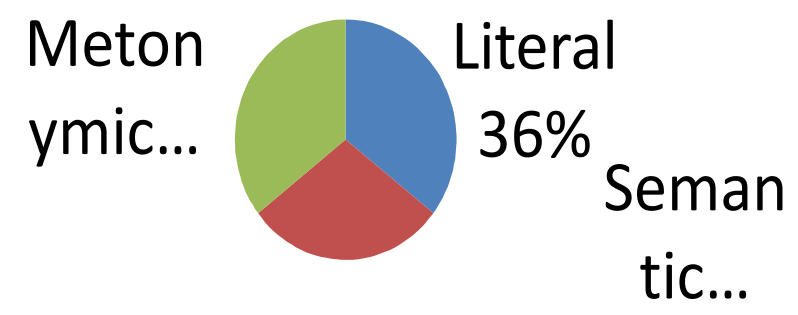

\section{Conclusion}

Quran is the word of God which cannot be reproduced by the word of man. Due to the diversity of languages, its translation in other languages for the guidance of all the living being is the need of the time. All those who used their faculty and scholarship to transfer the meaning of this divine book would surely be rewarded and honored. The above discussion shows the aptitude of the translators towards two consecutive metonymic Quranic phrases which can be concluded in the following points:

- The first metonymic phrase has been translated by 20 translators in a semantic form and 12 translators translated in a metonymic form whereas no literal translation was found.

- In the second phrase 11 translators rendered literal translations, 9 rendered semantic translations and 11 rendered metonymic translations.

- The sentence structures of all the translations create a beautiful blend of stylistics modification of the Quranic words.

- These variations clearly show that the word of God cannot be reproduced in a single way because every and single linguistic, morphological, syntactical unit contain various semantic shades with unrivalled, unmatched rhetorical features.

\section{References}

1 Chapter 4 Verse 43: http://altafsir.com/Tafasir

2 Chapter 4 Verse 43: http://altafsir.com/Tafasir

3 Chapter 4 Verse 43: http://altafsir.com/Tafasir

4 Privy: http://www.dictionary.com/browse/privy?s=t

5 https://www.google.com.pk/webhp?sourceid=chromeinstant\&ion $=1 \&$ espv $=2 \& i e=U T F-8 \# q=$ meaning + of + Privy 
6 Webster's New Collegiate Dictionary: p.916.

7 Closet: Reference Dictionary :

http://www.dictionary.com/browse/closet?s=t , Webster's New

Collegiate Dictionary , P.211

8 Relieve: Reference Dictionary:

http://www.dictionary.com/browse/relieve?s=t

9 Webster's New Collegiate Dictinary: Relieve: P.977

10 Dictionary.com: http://www.dictionary.com/browse/lavatory?s=t

11 Dictionary.com: http://www.dictionary.com/browse/defecate?s=t 4

12 Webster's New Collegiate Dictionary: Defecate: P.296

13 Dictionary: http://www.dictionary.com/browse/call-of-nature?s=t

14 Cambridge Dictionary: Call of Nature; http://dictionary.cambridge.org/dictionary/english/call-of-nature

15 Free Dictionary: Call of Nature; http://idioms.thefreedictionary.com/call+of+nature

16 Dictionary: http://www.dictionary.com/browse/relieve?s=t

17 Dictionary: http://www.dictionary.com/browse/toilet?s=t

18 Dictionary: http://www.dictionary.com/browse/unclean?\&o=100074\&s=t

19 Tabri: Verse 43 Chaper al-Nisa: http://www.altafsir.com/Tafasir.asp?tMadhNo=0\&tTafsirNo=1\&tSoraNo $=4 \& \mathrm{tAy} a \mathrm{hNo}=43 \& \mathrm{tDisplay}=\mathrm{ye} \& \mathrm{Page}=8 \&$ Size $=1 \&$ Language $\mathrm{Id}=1$

20 Razi. Verse 43 Chapter al-Nisa: http://www.altafsir.com/Tafasir.asp?tMadhNo=0\&tTafsirNo=4\&tSoraNo $=4 \& \mathrm{tAy}$ ahNo $=43 \& \mathrm{tDisplay}=\mathrm{yes} \& \mathrm{Page}=5 \&$ Size $=1 \&$ Language $\mathrm{Id}=1$

21 Dictionary: intercourse: http://www.dictionary.com/browse/intercourse? $\mathrm{s}=\mathrm{t}$

22 Dictionary: Cohabit: http://www.dictionary.com/browse/cohabited?s=t

23 Dictionary: Consort: http://www.dictionary.com/browse/consorted?s=t

24 Online Etymology Dictionary: Carnal: http://www.etymonline.com/index.php?allowed_in_frame $=0 \& \operatorname{search}=\mathrm{Ca}$ $\underline{\text { rnal+Relations }}$ 